\title{
Decontamination of cadmium(II) from synthetic wastewater onto shea fruit shell biomass
}

\author{
Jonas Bayuo ${ }^{1,2}$ (1) \\ Received: 13 December 2019 / Accepted: 19 April 2021 / Published online: 10 May 2021 \\ (c) The Author(s) 2021
}

\begin{abstract}
Shea fruit shells being an agricultural waste material was utilized to test its novelty as an inexpensive biosorbent for the elimination of $\mathrm{Cd}$ (II) from synthetic wastewater using the batch method. A batch study was employed to probe the impact of $\mathrm{pH}$ of the solution, contact time, temperature and initial concentration on the depollution of $\mathrm{Cd}(\mathrm{II})$ ions using unmodified Shea fruit shells biomass. The decontamination of Cd(II) by the unmodified Shea fruit shells biomass was found to be dependent on these adsorption parameters. The equilibrium data best represented Freundlich isotherm by a correlation coefficient $\left(R^{2}\right)$ of 0.9691 . The kinetic models analyzed suggest pseudo-second-order $\left(R^{2}=0.9515\right)$ as the best fit model signifying that the removal of Cd(II) ions was on account of chemisorption. The positive values of the thermodynamic parameters, $\Delta H^{\circ}$ and $\Delta S^{\circ}$ reveal endothermic and increase of disorder of the process while the negative charge of $\Delta G^{\circ}$ shows spontaneity of the system.
\end{abstract}

Keywords Biosorption $\cdot$ Equilibrium $\cdot$ Heavy metals $\cdot$ Kinetics $\cdot$ Thermodynamics

\section{Introduction}

Pollution by heavy metals in the natural environment has become a universal concern owing to their enduring and noxious effects on organisms when ingested beyond a certain concentration (Krika et al. 2016). Lead $(\mathrm{Pb})$, chromium $(\mathrm{Cr})$, cadmium $(\mathrm{Cd})$, zinc $(\mathrm{Zn})$, nickel $(\mathrm{Ni})$, copper $(\mathrm{Cu})$ and mercury $(\mathrm{Hg})$ are heavy metals that originate from battery manufacturing, petroleum refining, metal plating, paint manufacturing and mining activities (Njikam and Schiewer 2012).

Cadmium compounds are used in rechargeable Cadmium-Nickel (Cd-Ni) batteries, alloys, pigments, electronic compounds and stabilizers for polyvinyl chloride (Wuana and Okieimen 2011). Cadmium moves into the aquatic environment by dint of industrial effluent of Cadmium-Nickel batteries, mining, metal plating industries and metal alloys

Jonas Bayuo

jbayuo@cktutas.edu.gh; jonas87bayuo@yahoo.com

1 Department of Science and Mathematics Education, C. K. Tedam University of Technology and Applied Sciences, Postal Box 24, Navrongo, Upper East Region, Ghana

2 Department of Applied Chemistry and Biochemistry, C. K. Tedam University of Technology and Applied Sciences, Postal Box 24, Navrongo, Upper East Region, Ghana
(Krika et al. 2016). Cadmium can be inherent in the system for several years and has been ranked as the seventh most lethal metal and frequently present in battery manufacture, cement production, steel production and phosphate fertilizers (Ad et al. 2015). The detrimental effect of cadmium noxiousness in a human comprises pains in bones, impairment of the kidney in addition to its carcinogenic, teratogenicity and mutagenic effects (Emenike et al. 2016). Also, cadmium poisoning results in hypertension, testicular tissue damage, destruction of red blood cells, fishes and several marine species (Rao et al. 2011; Pfafflin and Zigler 2006).

Recently, many studies concluded that cadmium remains non-biodegradable when ingested into living systems and its circulation through the ecosystem is indestructible (Mutlu et al. 2012; Kumar et al. 2011). Cadmium exposure happens primarily through ingestion and inhalation and once it enters into the bloodstream, the erythrocytes transport it and at the intracellular phase, cadmium is engrossed to a portion of protein (Godt et al. 2006). Industrial effluents containing cadmium contaminants reach organisms via nutrition and become detrimental through bioaccumulation (Alfarra et al. 2014). The excessive exposure of cadmium to the human system has the tendency of being accumulated in the liver and renal cortex and consequently reallocates to the kidney during metallothionein production in the liver (Satarug et al. 2010). Åkesson et al. (2008) indicate that the kidneys 
accumulate $50 \%$ of cadmium load, $20 \%$ found in the muscles and the liver contains about $15 \%$. The acceptable limit of Cd(II) in potable aquatic sources is $5.00 \mu \mathrm{g} / \mathrm{L}$ according to European Union Standards. However, the concentration of cadmium in safe water sources is usually $<1.00 \mu \mathrm{g} / \mathrm{L}$ (Emenike et al. 2016).

The lives of humans could be made easy and comfortable through the decontamination of toxic heavy metals and keeping their concentration within tolerable values in drinking water using suitable treatment methods. Among these treatment techniques is the use of chemical reagents to precipitate metal ions from solution (Bayuo et al. 2018b; Meunier et al. 2006). Other methods applied in the field of water treatments are solvent extraction, coagulation-flocculation, membrane separation, electrocoagulation, cementation and ion exchange adsorptions (Bayuo et al. 2020). However, each of these methods formally used has its merits and limitations in applications such as the large volume of chemicals, tedious, high capital investments and consumes time.

In line with this, several new approaches and techniques have been investigated to develop effective methods to eliminate poisonous metals from aqueous media. Adsorption through commercial activated carbon has the capability of removing metals from inorganic effluents. However, commercial activated carbon is expensive but it has been used with great success because of its bulky surface area and reactivity (Krika et al. 2016). Attributable to the expensiveness of commercial adsorbents, several new approaches have been developed to decontaminate metals from wastewater by natural adsorbents. Many studies have indicated that the safest, easiest and most cost-effective method to depollute disastrous metals from effluents of industries is adsorption by natural biomass. Among others are groundnut husk (Bayuo et al. 2019a, b), cork powder (Krika et al. 2016) and sesame waste (Cheraghi et al. 2015).

Shea fruits grow on the African Shea tree also known as the Shea butter or Shea nut tree (Vitellaria paradoxa). Shea fruits are typically gathered and processed by locals and provide an important source of income for the people of the African sub-Saharan savanna. The fruits contain a relatively large and oily nut, used to make Shea butter while the fruit shells are usually thrown away or serve as a source of fuel.

Hence, in the current study, unmodified Shea fruit shells have been tested in the decontamination of Cd(II) from synthetic aqueous solutions.

\section{Materials and methods}

\section{Preparation of the adsorbent}

The Shea fruits were collected from a farm located at Pungu, Navrongo in the Upper East region of Ghana. The Shea fruits were treated with distilled water to thoroughly get rid of any contaminant. The shells were then removed and place in an oven to dry at a temperature of $110^{\circ} \mathrm{C}$ to a consistent mass and ground into powder form. Lastly, the powder was sieved by different mesh sizes ranging from $0.50-1.00 \mathrm{~mm}$ of particle size. The sample prepared was stored in airtight polythene bags and use for the batch adsorption tests.

\section{Preparation of $\mathrm{Cd}(\mathrm{II})$ ion solution}

Chemicals of analytical reagent grade and distilled water were utilized during the experimentations. A $2.672 \mathrm{~g}$ of cadmium nitrate $\left[\mathrm{Cd}\left(\mathrm{NO}_{3}\right)_{2} \cdot 4 \mathrm{H}_{2} \mathrm{O}\right]$ was dissolved in a volumetric flask with $200 \mathrm{~mL}$ distilled water and subsequently topup to a $1000-\mathrm{mL}$ mark of the volumetric flask to obtained a stock solution of $1000 \mathrm{mg} / \mathrm{L} \mathrm{Cd}(\mathrm{II})$. The bench solutions were prepared through serial dilution of the stock $\mathrm{Cd}(\mathrm{II})$ solutions by the distilled water. The $\mathrm{pH}$ of the initial aqueous solutions was adjusted by $0.10 \mathrm{M} \mathrm{HCl}$ and $\mathrm{NaOH}$.

\section{Batch experiments}

The elimination of $\mathrm{Cd}(\mathrm{II})$ ions onto unmodified Shea fruit shells was explored by batch mode.

The required amount of unmodified Shea fruit shells (UMSFS) biomass was agitated with $100 \mathrm{~mL}$ solutions of $\mathrm{Cd}$ (II) of desired concentration in $250-\mathrm{mL}$ flasks on a magnetic stirrer at $250 \mathrm{rpm}$. The mixture was filtered with Wattman 40 filter paper after agitation time was achieved and the amount of $\mathrm{Cd}(\mathrm{II})$ in the filtrate was obtained by the Spectrometry method [Atomic Absorption Spectrophotometer (AAS), NovAA 400p model]. The detection of Cd(II) concentrations was performed three times and readings of blank were taken from all the measurements.

The percentage decontamination and the $\mathrm{Cd}(\mathrm{II})$ ions adsorbed per unit mass of UMSFS at equilibrium time was evaluated by Eqs. (1) and (2), respectively (Bayuo et al. 2018b).

Re moval efficiency $(\%)=\left(C_{o}-C_{e} / C_{o}\right) \times 100$

where $C_{0}$ and $C_{\mathrm{e}}$ are $\mathrm{Cd}$ (II) initial and equilibrium concentrations $(\mathrm{mg} / \mathrm{L})$, respectively.

$q_{e}=\left(C_{o}=C_{e} / m\right) \times V$

where $q_{\mathrm{e}}$ denotes $\mathrm{Cd}(\mathrm{II})$ ions adsorbed per unit mass of UMSFS at equilibrium time, $V$ and $m$ are the solution volume $(\mathrm{mL})$ and UMSFS mass $(\mathrm{g})$, respectively.

\section{Effect of contact time}

Batch mode tests were performed by varying contact time and maintaining a constant solution $\mathrm{pH}$, UMSFS particle
要

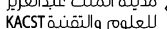


size, UMSFS dosage, initial Cd(II) concentration and solution temperature. The adsorbent was agitated at different times (15.00-180.00 min) with the adsorbate solutions. The required flasks containing the adsorbent-adsorbate mixtures were filtered and the $\mathrm{Cd}$ (II) concentration was measured by the means of AAS.

\section{Effect of initial pH of the solution}

The impact of the initial $\mathrm{pH}$ of solution on the sorption of $\mathrm{Cd}(\mathrm{II})$ was explored by adding $100 \mathrm{~mL}$ of $\mathrm{Cd}(\mathrm{II})$ solution in a flask. The desired initial $\mathrm{pH}$ of the aqueous solutions (2.00-13.00) was controlled by $0.10 \mathrm{M}$ of $\mathrm{HCl}$ and $\mathrm{NaOH}$ solutions using a portable $\mathrm{pH}$ meter. Independent variables like equilibrium contact time, UMSFS particle size, UMSFS dosage, initial $\mathrm{Cd}$ (II) concentration and solution temperature remained unchanged during the experiments. After equilibrium time, the $\mathrm{Cd}$ (II) concentration was measured by AAS and the sorption rate was calculated.

\section{Effect of initial Cd(II) concentration}

The influence of $\mathrm{Cd}(\mathrm{II})$ initial concentration was conducted by way of performing the adsorption experiments at an altered concentration of $\mathrm{Cd}(\mathrm{II})$ alternating from $10.00-50.00 \mathrm{mg} / \mathrm{L}$. The additional variables such as equilibrium time, optimum $\mathrm{pH}$ of the solution, UMSFS particle size, UMSFS dosage and temperature were kept constant. The adsorbent-adsorbate solution was stirred and after the optimum time, the concentration of $\mathrm{Cd}(\mathrm{II})$ in the filtrate after filtration was measured by AAS.

\section{Effect of solution temperature}

The batch mode tests were executed at five (5) diverse solution temperatures $\left(25.00-60.00{ }^{\circ} \mathrm{C}\right)$ using a magnetic stirrer with a heater. The reliability of the solution temperature was conserved with a precision of $\pm 0.50^{\circ} \mathrm{C}$ and parameters like optimum agitation time, solution $\mathrm{pH}$, UMSFS particle size, UMSFS dosage and initial Cd(II) concentration were kept constant. The $\mathrm{Cd}(\mathrm{II})$ concentration in the sample solutions was measured by AAS after the equilibrium time was accomplished.

\section{Results and discussion}

\section{Effect of contact time}

The results obtained from the impact of contact time by batch experiments are depicted in Fig. 1. Figure 1 revealed that the removal of $\mathrm{Cd}(\mathrm{II})$ from synthetic wastewater increased with increasing contact time. It was found that

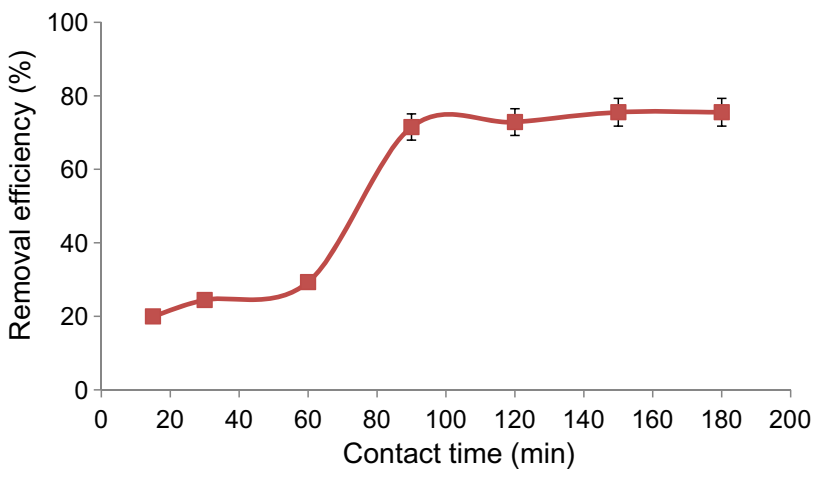

Fig. 1 Effect of contact time on the adsorption of $\mathrm{Cd}(\mathrm{II})$ ion onto UMSFS biomass

during the early stage, Cd(II) removal was rapid and later plateau until equilibrium was reached. This may probably indicate that there was a large initial concentration gradient between the $\mathrm{Cd}(\mathrm{II})$ ions in solution and accessible adsorption sites on the UMSFS surface (Bayuo et al. 2019b).

The UMSFS achieved maximum adsorption $(76.86 \%)$ of $\mathrm{Cd}(\mathrm{II})$ at about $150 \mathrm{~min}$ of contact time. Therefore, for all the other adsorption tests, $150 \mathrm{~min}$ was used as the equilibrium shaking time. The equilibrium time obtained in the current study is longer than those usually utilized for the adsorption of $\mathrm{Cd}(\mathrm{II})$ by other low-cost adsorbents. Among them include isolated green algae (Kumar et al. 2018); cork biomass (Krika et al. 2016); sponge gourd (Ad et al. 2015); Kaolinite and Metakaolinite clay (Essomba et al. 2014); sesame (Chen et al. 2011); maize stalks (El-Sayed et al. 2011).

\section{Effect of initial pH of the solution}

The sorption of heavy metals has been found to show dependence on the $\mathrm{pH}$ of the solution caused by its effect on the adsorbent surface charge, degree of ionization and adsorbent species (Ghoneim et al. 2014). The Cd(II) removal percent by UMSFS augmented with increasing initial $\mathrm{pH}$ of the solution as presented in Fig. 2. At higher $\mathrm{pH}$, fewer hydrogen ions were surrounded by the adsorbent thereby allowing $\mathrm{Cd}(\mathrm{II})$ to bind to accessible sorption locations of the adsorbent and maximum $\mathrm{Cd}(\mathrm{II})$ removal $(74.06 \%)$ was achieved by $\mathrm{pH}$ of 5.0. However, at a small initial $\mathrm{pH}$, the hydrogen ions undergo an active competition with $\mathrm{Cd}(\mathrm{II})$ ions for the number of vacant sorption locations on the adsorbent surface (Bayuo et al. 2019b; Ghoneim et al. 2014).

Cheraghi et al. (2015) conducted batch adsorption experiments to remove $\mathrm{Cd}(\mathrm{II})$ in the $\mathrm{pH}$ range of 2.0-9.0 while other parameters remained constant. The study shows that the best $\mathrm{pH}$ value was 6.0 and the removal efficiency of $\mathrm{Cd}(\mathrm{II})$ was found to increase from 33.45 to $92.95 \%$ with increasing $\mathrm{pH}$ value from 2.0-6.0. Subsequently, with

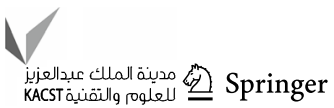




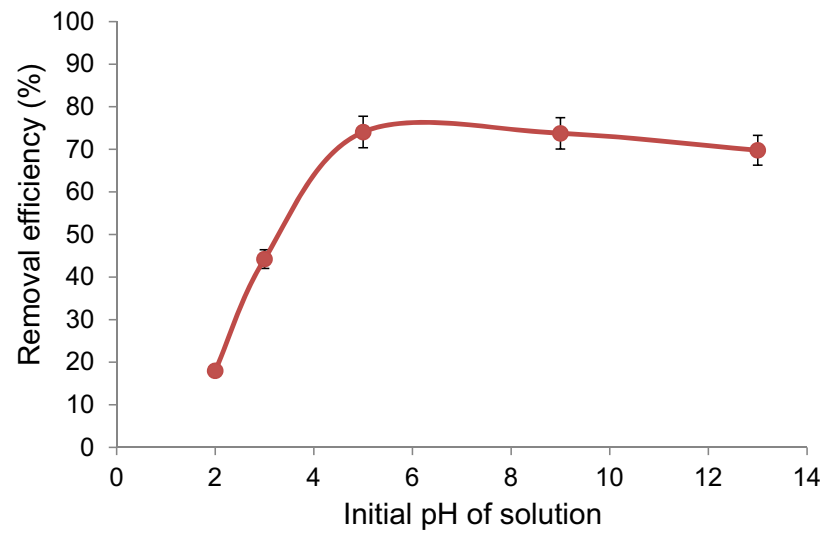

Fig. 2 Effect of $\mathrm{pH}$ of solution on the adsorption of $\mathrm{Cd}(\mathrm{II})$ ion onto UMSFS biomass

increasing $\mathrm{pH}$ value above 6.0, the percent removal of Cd(II) ions declined. Similarly, Essomba et al. (2014) varied pH between 3.0-10.0 to remove $\mathrm{Cd}$ (II) from aqueous solution using Kaolinite and Metakaolinite clay. It was found that at $\mathrm{pH}$ values higher than 8.0 insoluble cadmium hydroxide starts, precipitating from the solutions making true sorption studies impossible.

\section{Effect of $\mathrm{Cd}(\mathrm{II})$ initial concentration}

The influence of preliminary concentration on depolluting $\mathrm{Cd}(\mathrm{II})$ from the synthetic wastewater by UMSFS is depicted in Fig. 3. The sorption experimentations were investigated at $1.50 \mathrm{~g} / \mathrm{L}$ UMSFS dosage and initial solution $\mathrm{pH}$ of 5.0 under room temperature. Figure 3 reveals that the metal ions removal by UMSFS showed dependence on the initial molarity of $\mathrm{Cd}(\mathrm{II})$. At lower preliminary $\mathrm{Cd}(\mathrm{II})$ molarity, $\mathrm{Cd}(\mathrm{II})$ removal was higher than the higher initial amount of Cd(II). This may be because at a higher initial amount of

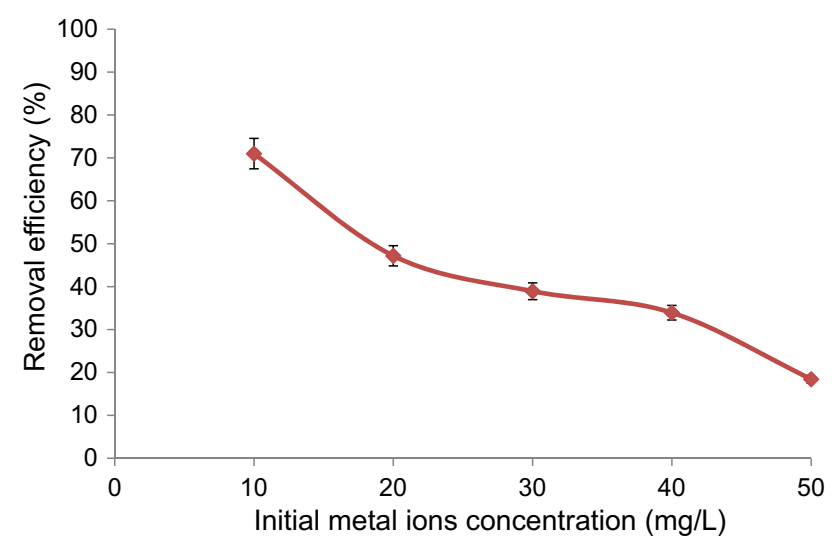

Fig. 3 Effect of initial concentration on the adsorption of $\mathrm{Cd}(\mathrm{II})$ ion onto UMSFS biomass
$\mathrm{Cd}(\mathrm{II})$, the available sorption sites on the UMSFS surface become saturated (Bayuo et al. 2019b). Similarly, El-Sayed et al. (2011) found that the percentage removal of $\mathrm{Cd}(\mathrm{II})$ decreased with increasing the initial metal ion concentration.

The optimal Cd(II) initial molarity determined in the present study is $10.00 \mathrm{mg} / \mathrm{L}$ with a percentage removal of $71.00 \%$. This maximum initial concentration of $\mathrm{Cd}(\mathrm{II})$ is consistent with the finding of Ghoneim et al. (2014) and Yang, (2011) where, $99.60 \%$ and $96.70 \%$ removal of Cd(II) ions were achieved at $10.00 \mathrm{mg} / \mathrm{L}$ and $\mathrm{pH}$ of 5.5 and 12.0 using marine green algae and bentonite, respectively.

\section{Effect of temperature}

Generally, the sorption process is highly dependent on the temperature of the solution. The influence of solution temperature on $\mathrm{Cd}(\mathrm{II})$ elimination was carried out at variable temperatures and maintaining other parameters constant. The removal efficiency of Cd(II) by UMSFS was improved from $25.00 \%$ to $62.93 \%$ until at about $40{ }^{\circ} \mathrm{C}$, where optimum removal $(66.93 \%)$ of $\mathrm{Cd}(\mathrm{II})$ was attained as presented by Fig. 4. The increase in removal efficiency of Cd(II) with increasing temperature might be because of the increasing diffusion rate of the solute across the outer periphery layer and subsequent adsorption onto the sorbent surface (Ghoneim et al. 2014). The attainment of Cd(II) maximum adsorption at higher temperatures by the UMSFS could describe the adsorption process to be due to chemisorption and endothermic (Bayuo et al. 2019b).

The finding of the effect of temperature in this study is similar to the results obtained by Mopoung and Kengkhetkit (2016) using $\mathrm{NaOH}$ treated pineapple waste. It was suggested that the higher temperature improves the trend by either increasing the number of available active sites or

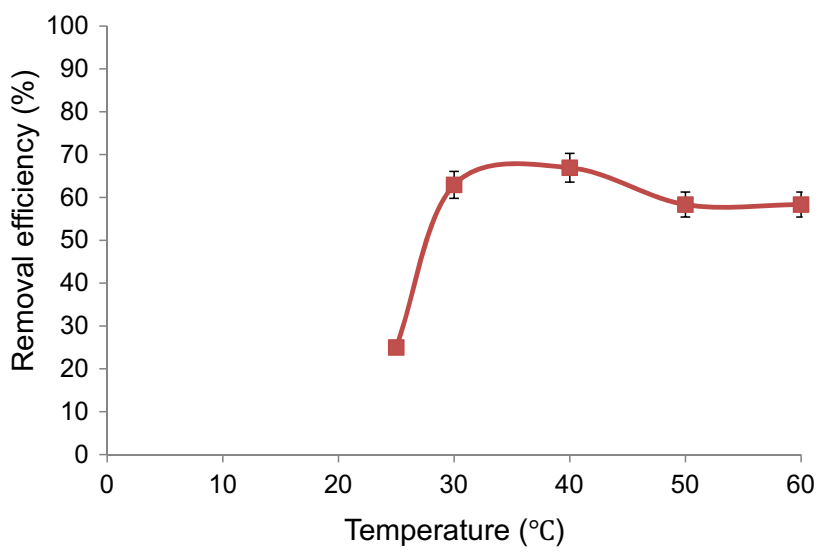

Fig. 4 Effect of temperature on the adsorption of $\mathrm{Cd}(\mathrm{II})$ ion onto UMSFS biomass 
decreasing the thickness of the boundary layer surrounding the adsorbents (Nguyen et al. 2013).

\section{Equilibrium adsorption isotherms}

In the determination of a best-fit model for designing the adsorption system, equilibrium isotherm data are usually analyzed by fitting into isotherm models (Othman et al. 2011). The adsorption capacity of UMSFS biomass was determined by fitting $\mathrm{Cd}$ (II) equilibrium data to Langmuir and Freundlich isotherms.

\section{Langmuir isotherm model}

The Langmuir model presumes that metal ions removal occurs on a homogenous sorbent surface by monolayer sorption without interaction among adsorbed ions (Bayuo et al. 2019a). The Langmuir model is often applied in the description of the optimal sorption rate of biosorbent and it is the utmost significant factor for the sorption process. It is expressed as given in Eq. (3) (Bayuo et al. 2018a):

$\frac{C_{\mathrm{e}}}{q_{\mathrm{e}}}=\frac{1}{q_{\mathrm{m}} K_{\mathrm{L}}}+\frac{C_{\mathrm{e}}}{q_{\mathrm{m}}}$

where $C_{\mathrm{e}}$ and $q_{\mathrm{e}}$ are $\mathrm{Cd}(\mathrm{II})$ concentration $(\mathrm{mg} / \mathrm{L})$ and adsorption capacity $(\mathrm{mg} / \mathrm{g})$ at equilibrium time, respectively. The constants $q_{\mathrm{m}}(\mathrm{mg} / \mathrm{g})$ and $K_{\mathrm{L}}(\mathrm{L} / \mathrm{mg})$ are associated with uptake capacity and net sorption enthalpy, respectively. The constants $q_{\mathrm{m}}$ and $K_{\mathrm{L}}$ are obtained by plotting $\frac{C_{\mathrm{e}}}{q_{\mathrm{e}}}$ versus $C_{\mathrm{e}}$ (Fig. 5) with a gradient; $\frac{C_{\mathrm{e}}}{q_{\mathrm{m}}}$ and intercept; $\frac{1}{q_{\mathrm{m}} K_{\mathrm{L}}}$.

The results of the equilibrium isotherm studies presented in Fig. 5 affirmed that the equilibrium data show good agreement with the Langmuir model with a determination coefficient $\left(R^{2}\right)$ of 0.8829 and monolayer adsorption capacity of $25.4453 \mathrm{mg} / \mathrm{g}$ as summarized in Table 1 . The Langmuir fit is consistent with strong monolayer and homogeneous $\mathrm{Cd}(\mathrm{II})$

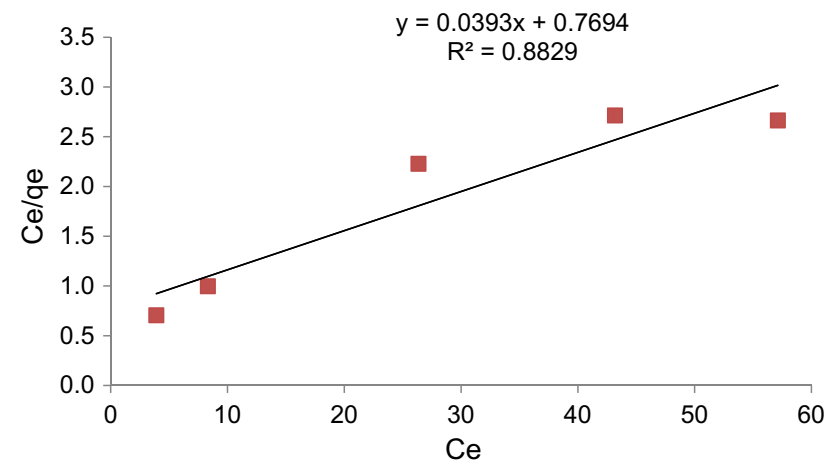

Fig. 5 Langmuir adsorption isotherm plot of Cd(II) ion onto UMSFS biomass
Table 1 Langmuir and Freundlich model constants for Cd(II) sorption by UMSFS biomass

\begin{tabular}{llr}
\hline Model & Parameter & \multicolumn{1}{c}{ Value } \\
\hline Langmuir & $q_{\mathrm{m}}(\mathrm{mg} / \mathrm{g})$ & 25.4453 \\
& $K_{\mathrm{L}}(\mathrm{L} / \mathrm{mg})$ & 0.0302 \\
& $R_{\mathrm{L}}$ & 0.4484 \\
& $R^{2}$ & 0.8829 \\
Freundlich & $K_{\mathrm{F}}(\mathrm{mg} / \mathrm{g})$ & 0.3371 \\
& $\mathrm{n}$ & 2.1739 \\
& $\frac{1}{n}$ & 0.4600 \\
& $R^{2}$ & 0.9691 \\
\hline
\end{tabular}

sorption onto specific sites on the UMSFS biomass (Bayuo et al. 2019b).

Additionally, the indispensable feature of the Langmuir model is expressed in relation to a dimensionless coefficient separation variable (Bayuo et al. 2019b):

$R_{L}=\frac{1}{1+K_{\mathrm{L}} C_{0}}$

where $R_{L}$ and $K_{\mathrm{L}}$ are variable of separation and Langmuir constant $(\mathrm{L} / \mathrm{mg})$, respectively, while $C_{0}$ is initial adsorbate molarity (mg/L). The value of $R_{L}(0.4484)$ attained during $\mathrm{Cd}(\mathrm{II})$ decontamination by UMSFS biomass is between 0 and 1 implying a suitable sorption process (Bayuo et al. 2019a). Thus, the experimental data exhibited efficient Cd(II) removal by UMSFS biomass in this study.

\section{Freundlich isotherm model}

The Freundlich empirical isotherm is applicable for demonstrating sorption on heterogeneous biosorbent surfaces. The linearized form of the Freundlich model is given by Eq. (4) (Bayuo et al. 2018b).

$\log q_{e}=\log K_{\mathrm{F}}+\frac{1}{\mathrm{n}} \log C_{\mathrm{e}}$

where $C_{\mathrm{e}}$ and $q_{\mathrm{e}}$ are $\mathrm{Cd}(\mathrm{II})$ concentration $(\mathrm{mg} / \mathrm{L})$ and adsorption capacity $(\mathrm{mg} / \mathrm{g})$ at equilibrium time, respectively. The constant $K_{\mathrm{F}}$ and $n$ are relative sorption ability $(\mathrm{mg} / \mathrm{g}$ ) and intensity of the biomass, respectively. By plotting $\log q_{e}$ against $\log C_{\mathrm{e}}$ (Fig. 6), the coefficients $n$ and $K_{\mathrm{F}}$ are determined from the gradient; $\frac{1}{\mathrm{n}}$ and intercept; $\log \mathrm{K}_{\mathrm{F}}$, respectively.

The results of Fig. 6 showed that Cd(II) equilibrium data represented Freundlich isotherm well than that of the Langmuir by a determination coefficient of 0.9691 . This implied that $\mathrm{Cd}(\mathrm{II})$ biosorption occurred on the heterogeneous surfaces of UMSFS biomass (Bayuo et al. 2019a). Moreover, in Table $1, K_{F}$ is 0.3371 implying Cd(II) maximal sorption capacity by UMSFS (Ghoneim et al. 2014) and the value of $\frac{1}{n}$ 


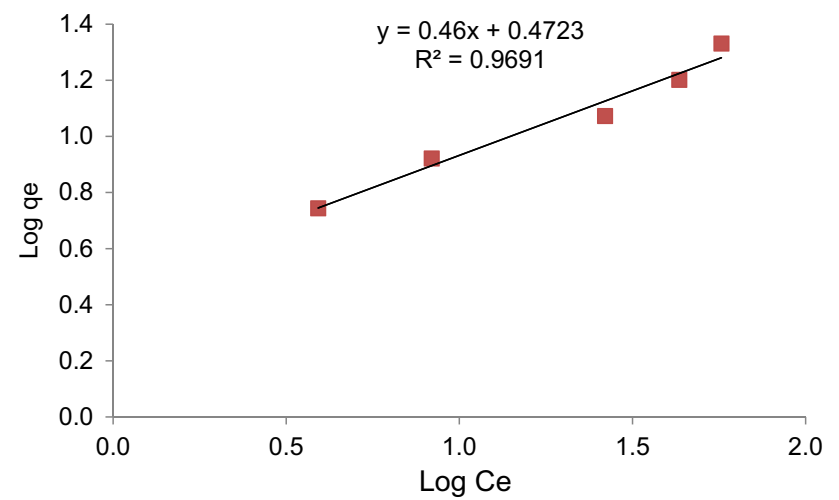

Fig. 6 Freundlich adsorption isotherm plot of $\mathrm{Cd}$ (II) ion onto UMSFS biomass

(0.4600) lies between 0 and 1 suggesting sufficient sorption (Bayuo et al. 2018a).

The better fitness of the Freundlich model to the equilibrium data than that of the Langmuir model conforms to the results of Sukpreabprom et al. 2014 who investigated the removal of $\mathrm{Cd}(\mathrm{II})$ using bottom ash. However, the findings of this study contradict other studies carried out to remove Cd(II) using cheap biosorbents in which the Langmuir model shows a dominant fit to the experimental data (Habte et al. 2020; Kumar et al. 2018; Kabir et al. 2015).

\section{Equilibrium adsorption kinetics}

The speed upon which adsorption takes place plays a major role in planning batch technique tests. Therefore, it is important to determine the sorption kinetics that can confirm the exploration of the superlative model that could describe the kinetic data well. The present study applied pseudo-first and pseudo-second-order kinetic models to simulate $\mathrm{Cd}(\mathrm{II})$ experimental data by UMSFS biomass.

\section{Pseudo-first-order kinetic model}

The pseudo-first-order kinetic model is generally used globally for the projection of sorption tests of metal ions. The linearized form is expressed in Eq. (6) (Bayuo et al. 2020).

$\log \left(q_{\mathrm{e}}-q_{\mathrm{t}}\right)=\log q_{\mathrm{e}}-\frac{k_{\mathrm{p}_{1}}}{2.303} \mathrm{t}$

where $k_{\mathrm{p}_{1}}\left(\mathrm{~min}^{-1}\right)$ is rate constant of pseudo-first-order, $q_{\mathrm{e}}$ and $q_{\mathrm{t}}(\mathrm{mg} / \mathrm{g})$ are equilibrium and specific time (min) sorption rates, respectively.

The plot of $\log \left(q_{\mathrm{e}}-q_{\mathrm{t}}\right)$ versus $\mathrm{t}$ of the pseudo-first-order model is depicted in Fig. 7.

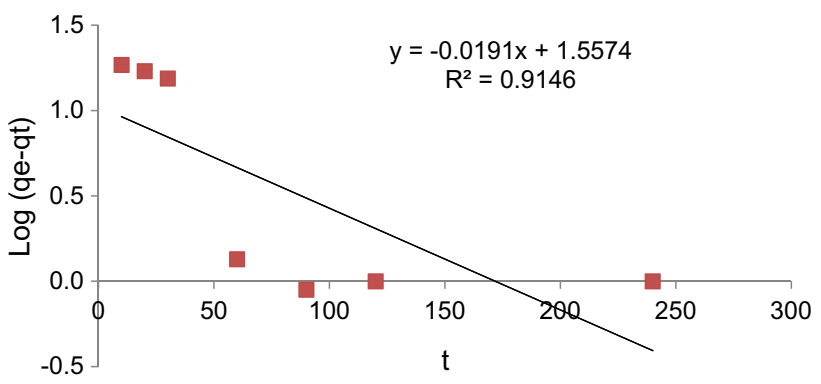

Fig. 7 Pseudo-first-order plot of Cd(II) onto UMSFS biomass

\section{Pseudo-second-order kinetic model}

It is been established that the pseudo-second-order model has been explored extensively to elucidate inorganic and organic compounds adsorption on different biosorbents and formulated in the form (Bayuo et al. 2020):

$\frac{\mathrm{t}}{q_{\mathrm{t}}}=\frac{1}{k_{\mathrm{p}_{2}} q_{\mathrm{e}^{2}}}+\frac{1}{q_{\mathrm{e}}} \mathrm{t}$

where $k_{\mathrm{p}_{2}}\left(\mathrm{gmg}^{-1} \mathrm{~min}^{-1}\right)$ is the rate constant of pseudo-second-order, $q_{\mathrm{e}}$ and $q_{\mathrm{t}}(\mathrm{mg} / \mathrm{g})$ are equilibrium and specific time (min) sorption rates, respectively. The pseudo-second-order model plot is given as $\frac{\mathrm{t}}{q_{\mathrm{t}}}$ versus $\mathrm{t}$ as presented in Fig. 8 .

From the kinetic model plots, the various model constants and correlation coefficients were calculated as summarized in Table 2. The correlation coefficients of the pseudo-first and pseudo-second-order kinetic equations were 0.9146 and 0.9515 as illustrated in Figs. 7 and 8, respectively. The higher correlation coefficient of the pseudo-second-order kinetic equation suggests that the equilibrium data have shown a good representation of the model (Bayuo et al. 2020, 2018b). The agreement of the equilibrium data to the pseudo-second-order equation implies that $\mathrm{Cd}$ (II) decontamination by UMSFS biomass may be due to chemical adsorption and hence, the rate-limiting step. Furthermore,

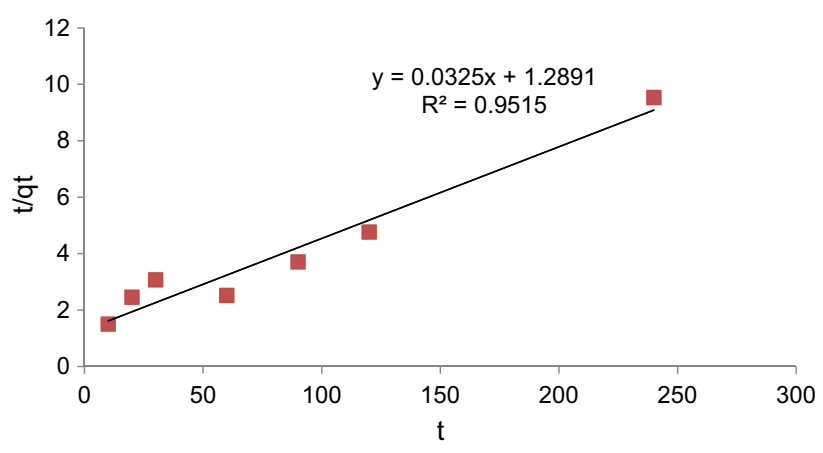

Fig. 8 Pseudo-second-order plot of Cd(II) onto UMSFS biomass 
Table 2 Kinetic model constants and their correlation coefficients $\left(R^{2}\right)$ for Cd(II) removal by UMSFS biomass

\begin{tabular}{lll}
\hline Kinetic model & Parameter & Parameter value \\
\hline Pseudo-first-order & $K \mathrm{p}_{1}(\mathrm{~L} / \mathrm{min})$ & 0.0440 \\
& $q_{e}(\mathrm{mg} / \mathrm{g})$ & 0.0277 \\
& $R^{2}$ & 0.9146 \\
Pseudo-second-order & $K \mathrm{p}_{2}(\mathrm{~L} / \mathrm{min})$ & 0.0008 \\
& $q_{e}(\mathrm{mg} / \mathrm{g})$ & 30.7692 \\
& $R^{2}$ & 0.9515 \\
\hline
\end{tabular}

the closeness of the correlation coefficient values of the pseudo-first and pseudo-second-orders kinetic equations shows that the sorption system adopted an intra-particle diffusion model with one or more mechanisms influencing the sorption system (Cheraghi et al. 2015).

The good conformity of the pseudo-second-order model to the equilibrium data in comparison to the pseudo-firstorder model is similar to the findings of several studies conducted to remove $\mathrm{Cd}$ (II) with other cheap biosorbents (Kumar et al. 2018; Krika et al. 2016; Ad et al. 2015; Cheraghi et al. 2015; Othman et al. 2011).

\section{Adsorption thermodynamic studies}

Enthalpy, entropy and Gibbs free energy are the thermodynamic parameters that should be evaluated before the spontaneity of the system can be inferred. Gibbs free energy $\left(\mathrm{G}^{0}\right)$ is regarded as the spontaneity indicator of a chemical reaction (Ho and Ofomaja 2006). The Gibbs free energy $\left(\Delta G^{0}\right)$ of sorption can be written in relation to Langmuir adsorption constant by the equation (Krika et al. 2016):

$\Delta \mathrm{G}^{0}=-\mathrm{RT} \ln K_{\mathrm{L}}$

The Gibbs free energy change $\left(\Delta \mathrm{G}^{0}\right)$ is linked to the change in enthalpy $\left(\Delta \mathrm{H}^{0}\right)$ and entropy $\left(\Delta \mathrm{S}^{0}\right)$ under constant temperature as expressed in Eq. (9).

$\Delta \mathrm{G}^{\circ}=\Delta \mathrm{H}^{\circ}-\mathrm{T} \Delta \mathrm{S}^{\circ}$

Combining Eqs. (8) and (9) yields Eq. (10):

$\ln K_{\mathrm{L}} \frac{\Delta \mathrm{S}^{\circ}}{\mathrm{R}}=\frac{\Delta \mathrm{H}^{\circ}}{\mathrm{RT}}$

where $\mathrm{R}$ denotes the ideal gas constant $\left(8.314 \mathrm{Jmol}^{-1} \mathrm{~K}^{-1}\right)$, $K_{L}$ represents the distribution coefficient for the adsorption $\left(\mathrm{mLg}^{-1}\right)$ and $\mathrm{T}(K)$ signifies absolute solution temperature. The values of $\Delta \mathrm{H}^{\circ}$ and $\Delta \mathrm{S}^{\circ}$ are obtained from $\frac{-\Delta \mathrm{H}^{\circ}}{\mathrm{R}}$ (slope) and $\frac{-\Delta \mathrm{S}^{2}}{\mathrm{R}}$ (intercept) by plotting $\ln K_{L}$ versus $1 / T$.

The experimental data of the thermodynamics study reveals that the $\Delta \mathrm{G}^{\mathrm{o}}\left(-2.7702 \mathrm{~kJ} \mathrm{~mol}^{-1}\right)$ of the sorption system is negative indicating the feasibility and spontaneous nature of $\mathrm{Cd}(\mathrm{II})$ biosorption by the UMSFS biomass. The positive value of $\Delta \mathrm{H}^{\mathrm{o}}\left(32.7634 \mathrm{~kJ} \mathrm{~mol}^{-1}\right)$ indicates chemisorption and endothermic nature of the sorption system while the positive value of $\Delta \mathrm{S}^{\mathrm{o}}\left(0.1135 \mathrm{~kJ} \mathrm{~K}^{-1} \mathrm{~mol}^{-1}\right)$ shows an increase of disorder at the solute-solvent interface for the period of $\mathrm{Cd}(\mathrm{II})$ depollution by the UMSFS biomass (Krika et al. 2016). The results of the thermodynamic studies conformed to the results of Bulut and Tez (2007) who investigated the decontamination of $\mathrm{Pb}(\mathrm{II})$, $\mathrm{Ni}$ (II) and $\mathrm{Cd}(\mathrm{II})$ from aqueous media using sawdust. The thermodynamic variables evaluated in their study confirm the spontaneity and endothermic nature of the sorption procedure.

\section{Conclusion}

Batch adsorption studies were conducted using UMSFS biomass to eliminate $\mathrm{Cd}(\mathrm{II})$ from synthetic wastewater. The study indicates the adsorbent's suitability to eliminate Cd(II). Therefore, when considering the economic aspects of wastewater treatment, the selected adsorbent is recognized as a valuable material.

The biosorption rate of Cd(II) onto the UMSFS biomass shows dependence on the independent sorption variables (factors). For instance, the removal efficiency was improved with rising agitation time until equilibrium time was attained at $150 \mathrm{~min}$. The sorption process was favored by increasing the $\mathrm{pH}$ of the initial solutions. The optimal initial solution $\mathrm{pH}$ was accomplished at a $\mathrm{pH}$ of 5.0 with $74.06 \% \mathrm{Cd}$ (II) removal. Furthermore, $\mathrm{Cd}(\mathrm{II})$ biosorption was higher at low-level Cd(II) molarity and maximum Cd(II) uptake was at $10.00 \mathrm{mg} / \mathrm{L}$. More so, Cd(II) decontamination was enhanced by intensifying solution temperature until the equilibrium sorption state was achieved at $40{ }^{\circ} \mathrm{C}$.

The equilibrium isotherm and kinetic studies reveal good fitness of the equilibrium data to Freundlich isotherm and pseudo-second-order kinetic models.

The positive enthalpy and entropy values implied endodermic (chemisorption) and an increase of randomness during the sorption process. The negative $\Delta G^{\mathrm{o}}$ value reflects the feasibility and spontaneous nature of the system.

Funding No specific funding was received for this work.

\section{Declarations}

Conflict of interest The author reports no conflict of interest.

Open Access This article is licensed under a Creative Commons Attribution 4.0 International License, which permits use, sharing, adaptation, distribution and reproduction in any medium or format, as long as you give appropriate credit to the original author(s) and the source, provide a link to the Creative Commons licence, and indicate if changes were made. The images or other third party material in this article are included in the article's Creative Commons licence, unless indicated otherwise in a credit line to the material. If material is not included in 
the article's Creative Commons licence and your intended use is not permitted by statutory regulation or exceeds the permitted use, you will need to obtain permission directly from the copyright holder. To view a copy of this licence, visit http://creativecommons.org/licenses/by/4.0/.

\section{References}

Ad C, Benalia M, Laidani Y, Elmsellem H, Ben Saffedine F, Nouacer I, Hammouti B (2015) Adsorptive removal of cadmium from aqueous solution by Luffa Cylindrica: equilibrium, dynamic and thermodynamic. Der Pharma Chemica 7(12):388-397

Åkesson A, Julin B, Wolk A (2008) Long-term dietary cadmium intake and postmenopausal endometrial cancer incidence: A populationbased prospective cohort study. Can Res 68(15):6435-6441. https://doi.org/10.1158/0008-5472.CAN-08-0329

Alfarra RS, Ali NE, Yusoff MM (2014) Removal of heavy metals by natural adsorbent: a review. Int J Biosci IJB 6655:130-139. https://doi.org/10.12692/ijb/4.7.130-139

Bayuo J, Pelig-Ba KB, Abukari MA (2018) Isotherm modeling of lead (II) adsorption from aqueous solution using groundnut shell as a low-cost adsorbent. IOSR J Appl Chem (IOSR-JAC) 11(11):1823. https://doi.org/10.9790/5736-1111011823

Bayuo J, Abukari MA, Pelig-Ba KB (2018b) Equilibrium isotherm studies for the sorption of hexavalent chromium (VI) onto groundnut shell. IOSR J Appl Chem (IOSR-JAC) 11(12):40-46. https:// doi.org/10.9790/5736-1112014046

Bayuo J, Pelig-Ba KB, Abukari MA (2019) Optimization of adsorption parameters for effective removal of lead (II) from aqueous solution. Phys Chem : Indian J 14(1):1-25

Bayuo J, Pelig-Ba KB, Abukari MA (2019) Adsorptive removal of chromium(VI) from aqueous solution unto groundnut shell. Appl Water Sci 9(4):1-11. https://doi.org/10.1007/s13201-019-0987-8

Bayuo J, Abdullai MA, Pelig-Ba KB (2020) Optimization using central composite design (CCD) of response surface methodology (RSM) for biosorption of hexavalent chromium from aqueous media. Appl Water Sci 10(6):1-12. https://doi.org/10.1007/ s13201-020-01213-3

Bulut Y, Tez Z (2007) Removal of heavy metals from aqueous solution by sawdust adsorption. J Environ Sci 19(2):160-166. https://doi. org/10.1016/S1001-0742(07)60026-6

Chen YG, Ye WM, Yang XM, Deng FY, He Y (2011) Effect of contact time, $\mathrm{pH}$, and ionic strength on $\mathrm{Cd}(\mathrm{II})$ adsorption from aqueous solution onto bentonite. Environ Earth Sci 64(2):329-336. https:// doi.org/10.1007/s12665-010-0850-6

Cheraghi E, Ameri E, Moheb A (2015) Adsorption of cadmium ions from aqueous solutions using sesame as a low-cost biosorbent: kinetics and equilibrium studies. Int J Environ Sci Technol 12(8):2579-2592. https://doi.org/10.1007/s13762-015-0812-3

El-Sayed GO, Dessoukia H, Ibrahiem SS (2011) Removal of Zn(II), $\mathrm{Cd}(\mathrm{II})$ and $\mathrm{Mn}(\mathrm{II})$ from aqueous solutions by adsorption on maize stalks. Malays J Anal Sci 15(1):8-21

Emenike PC, Omole DO, Ngene BU, Tenebe IT (2016) Potentiality of agricultural adsorbent for the sequestering of metal ions from wastewater. Global J Environ Sci Manage 2(4):411-442. https:// doi.org/10.22034/gjesm.2016.02.04.010

Essomba JS, Nsami JNDI, Desire P, Belibi B, Tagne GM, Mbadcam JK (2014) Adsorption of cadmium (II) ions from aqueous solution onto kaolinite and metakaolinite. Pure and Appl Chem Sci 2(1):11-30

Ghoneim MM, El-desoky HS, El-moselhy KM, Amer A, El-naga EHA, Mohamedein LI, Al-prol AE (2014) Removal of cadmium from aqueous solution using marine green algae, Ulva lactuca. Egypt J Aquatic Res 40(3):235-242. https://doi.org/10.1016/j.ejar.2014. 08.005
Godt J, Scheidig F, Grosse-Siestrup C, Esche V, Brandenburg P, Reich A, Groneberga D (2006) The toxicity of cadmium and resulting hazards for human health. J Occup Med Toxicol (London, England) 1:22. https://doi.org/10.1186/1745-6673-1-22

Habte L, Shiferaw N, Khan MD, Thriveni T, Ahn J (2020) Sorption of $\mathrm{Cd}(\mathrm{II})$ and $\mathrm{Pb}$ (II) on aragonite synthesized from eggshell. Sustainability 12(1174):1-15. https://doi.org/10.3390/su12031174

Ho Y, Ofomaja A (2006) Biosorption thermodynamics of cadmium on coconut copra meal as biosorbent. Biochem Eng J 30(2):117-123. https://doi.org/10.1016/j.bej.2006.02.012

Kabir AS, Umar BA (2015) Biosorption of Cd(II) from aqueous solution using Papaya (Carica papaya) seed: equilibrium and Kinetic studies. Merit Res J Environ Sci Toxicol 3(8):83-90

Krika F, Azzouz N, Ncibi MC (2016) Adsorptive removal of cadmium from aqueous solution by cork biomass: equilibrium, dynamic and thermodynamic studies. Arab J Chem 9:S1077-S1083. https://doi. org/10.1016/j.arabjc.2011.12.013

Kumar M, Singh A, Sikandar M (2018) Study of sorption and desorption of Cd (II) from aqueous solution using isolated green algae Chlorella vulgaris. Appl Water Sci 8(8):1-11. https://doi.org/10. 1007/s13201-018-0871-y

Kumar PS, Ramalingam S, Vijayakumar R, Kirupha SD, Murugesan A, Sivanesan S (2011) Adsorption of metal ions onto the chemically modified agricultural waste. Clean- Soil, Air, Water 40(2):188197. https://doi.org/10.1002/clen.201100118

Meunier N, Drogui P, Montane C, Hausier R, Mercier G, Blais JF (2006) Comparison between electro coagulation and chemical precipitation for metal from acidic soil leachate. J Hazard Mater B 137:581-590

Mopoung R, Kengkhetkit N (2016) Lead and cadmium removal efficiency from aqueous solution by $\mathrm{NaOH}$ treated pineapple waste. Int J Appl Chem 12(1):23-35

Mutlu A, Lee BK, Park GH, Yu BG, Lee CH (2012) Long-term concentrations of airborne cadmium in metropolitan cities in Korea and potential health risks. Atmos Environ 47:164-173. https://doi. org/10.1016/j.atmosenv.2011.11.019

Nguyen TAH, Ngo HH, Guo WS, Zhang J, Liang S, Yue QY, Nguyen TV (2013) Applicability of agricultural waste and by-products for adsorptive removal of heavy metals from wastewater. Bioresour Technol 148:574-585. https://doi.org/10.1016/j.biortech.2013.08.124

Njikam E, Schiewer S (2012) Optimization and kinetic modeling of cadmium desorption from citrus peels: a process for biosorbent regeneration. J Hazard Mater 213:242-248. https://doi.org/10. 1016/j.jhazmat.2012.01.084

Othman ZA, Ala H, ZA, Habila (2011) Kinetic, equilibrium and thermodynamic studies of cadmium (II) adsorption by modified agricultural wastes. Molecules 16(12):10443-10456. https://doi.org/ $10.3390 /$ molecules 161210443

Pfafflin JR, Zigler EN (2006) Encyclopedia of environmental science and engineering in choice reviews online (vol 44). Mc Graw-Hill

Rao K, Mohapatra M, Anand S, Venkateswarlu P (2011) Review on cadmium removal from aqueous solutions. Int J Eng Sci Technol 2(7):81-103. https://doi.org/10.4314/ijest.v2i7.63747

Satarug S, Garrett SH, Sens MA, Sens DA (2010) Cadmium, environmental exposure, and health outcomes. Environ Health Perspect 118(2):182-190. https://doi.org/10.1289/ehp.0901234

Sukpreabprom H, Arquero O, Naksata W, Sooksamiti P, Janhom S (2014) Isotherm, kinetic and thermodynamic studies on the adsorption of $\mathrm{Cd}(\mathrm{II})$ and $\mathrm{Zn}$ (II) ions from Aqueous Solutions onto Bottom Ash. Int J Environ Sci Develop. https://doi.org/10. 7763/IJESD.2014.V5.471

Wuana RA, Okieimen FE (2011) Heavy metals in contaminated soil. ISRN Ecol. https://doi.org/10.5402/2011/402647

Publisher's Note Springer Nature remains neutral with regard to jurisdictional claims in published maps and institutional affiliations. 